\title{
Assessment of Water Quality in Asa River (Nigeria) and Its Indigenous Clarias gariepinus Fish
}

\author{
Olatunji M. Kolawole ${ }^{1,2, *}$, Kolawole T. Ajayi ${ }^{2}$, Albert B. Olayemi ${ }^{2}$ and Anthony I. Okoh ${ }^{1}$ \\ 1 Applied and Environmental Microbiology Research Group, Department of Biochemistry and \\ Microbiology, University of Fort Hare, Private Bag X1314, King William's Town Road, \\ Alice 5700, South Africa; E-Mail: aokoh@ufh.ac.za \\ 2 Infectious Diseases and Environmental Health Research Group, Department of Microbiology, \\ University of Ilorin, P.M.B. 1515, Ilorin, Nigeria; E-Mails: kolatemaj@yahoo.com (K.T.A.); \\ bolayemi_2005@yahoo.com (A.B.O.)
}

* Author to whom correspondence should be addressed; E-Mail: mkolawole@ufh.ac.za; Tel.: +277-3386-2937.

Received: 27 September 2011; in revised form: 15 November 2011 / Accepted: 16 November 2011 / Published: 18 November 2011

\begin{abstract}
Water is a valued natural resource for the existence of all living organisms. Management of the quality of this precious resource is, therefore, of special importance. In this study river water samples were collected and analysed for physicochemical and bacteriological evaluation of pollution in the Unity Road stream segment of Asa River in Ilorin, Nigeria. Juvenile samples of Clarias gariepinus fish were also collected from the experimental Asa River and from the control Asa Dam water and were analysed for comparative histological investigations and bacterial density in the liver and intestine in order to evaluate the impact of pollution on the aquatic biota. The water $\mathrm{pH}$ was found to range from 6.32 to 6.43 with a mean temperature range of 24.3 to $25.8{ }^{\circ} \mathrm{C}$. Other physicochemical parameters monitored including total suspended solids, total dissolved solids, biochemical oxygen demand and chemical oxygen demand values exceeded the recommended level for surface water quality. Results of bacteriological analyses including total heterotrophic count, total coliform and thermotolerant coliform counts revealed a high level of faecal pollution of the river. Histological investigations revealed no significant alterations in tissue structure, but a notable comparative distinction of higher bacterial density in the intestine and liver tissues of Clarias gariepinus from Asa River than in those
\end{abstract}


collected from the control. It was inferred that the downstream Asa River is polluted and its aquatic biota is bacteriologically contaminated and unsafe for human and animal consumption.

Keywords: Asa River; physicochemical parameters; histological; water quality; pollution

\section{Introduction}

Water is vital to the existence of all living organisms, but this valued resource is increasingly being threatened as human populations grow and demand more water of high quality for domestic purposes and economic activities [1]. The quality of any body of surface or ground water is a function of either or both natural influences and human activities [2,3]. It is now generally accepted that aquatic environments cannot be perceived simply as holding tanks that supply water for human activities. Rather, these environments are complex matrices that require careful use to ensure sustainable ecosystem functioning well into the future [1].

Rivers are the most important freshwater resource for man. Unfortunately, river waters are being polluted by indiscriminate disposal of sewerage, industrial waste and plethora of human activities, which affects their physico-chemical characteristics and microbiological quality [4]. Pollution of the aquatic environment is a serious and growing problem. Increasing numbers and amounts of industrial, agricultural and commercial chemicals discharged into the aquatic environment have led to various deleterious effects on aquatic organisms. Aquatic organisms, including fish, accumulate pollutants directly from contaminated water and indirectly via the food chain $[5,6]$.

Owing to the large quantity of effluent discharged to the receiving waters, the natural processes of pathogen reduction are inadequate for protection of public health. In addition, industrial wastes that alter the water $\mathrm{pH}$ and provide excessive bacterial nutrients often compromise the ability of natural processes to inactivate and destroy pathogens [7]. The extent of discharge of domestic and industrial effluents is such that rivers receiving untreated effluent cannot provide the dilution necessary for their survival as good quality water sources. The transfer of unfavourable releases from industries is detrimental to human and animal health and safety [8]. Disposal of sewage wastes into a large volume of water could increase the biological oxygen demands to such a high level that all the available oxygen may be removed, consequently causing the death of all aerobic species, e.g., fish [9].

Prevention of river pollution requires effective monitoring of physico-chemical and microbiological parameters [10]. In most countries, the principal risks to human health associated with the consumption of polluted water are microbiological in nature [11].The bacteriological examination of water has a special significance in pollution studies, as it is a direct measurement of deleterious effect of pollution on human health [12]. Coliforms are the major microbial indicator of monitoring water quality [13,14]. The detection of Escherichia coli provides definite evidence of faecal pollution; in practice, the detection of thermotolerant (faecal) coliform bacteria is an acceptable alternative [11].

Histopathological alterations can also be used as indicators for the effects of various anthropogenic pollutants on aquatic biota and are a reflection of the overall health of the entire population in the 
ecosystem [6]. Histopathological changes have been widely used as biomarkers in the evaluation of the health of fish exposed to contaminants, both in the laboratory [15-17] and field studies [18-20].

Asa River is a major river of economic, agricultural and environmental significance in Ilorin - the capital city of Kwara State, Nigeria. The river receives effluents from industries located along its course, apart from domestic wastes and other activities carried out along it that contribute to its pollution. It was also reported that the major identified source of pollution of Asa River was direct runoff of effluents from the industries [8]. Moreover, it was pointed out that the river is subject to high level of eutrophication due to the organic matter and industrial effluents discharged into it [21]. This informed the need to evaluate the impact of pollution on the river segment and its aquatic biota. A study of this kind has not been carried out on the river.

Our group aimed to assess the ecological and public-health aspects of pollution impact on the experimental Asa River segment by determining the physicochemical parameters, bacteriological river water quality indicators and histological investigations for possible pathologic effects and bacterial density in the viscera of indigenous samples of catfish (Clarias gariepinus), a commercially important fish. Clarias gariepinus is common in Nigerian rivers, including Asa River, and it is consumed by many in Ilorin city.

\section{Materials and Methods}

\subsection{Study Area}

The study was conducted on the Asa River segment at the exit of the industrial estate around Unity Road, Ilorin, North Central Nigeria $\left(8^{\circ} 28^{\prime} \mathrm{N}, 4^{\circ} 38^{\prime} \mathrm{E}\right.$ to $\left.8^{\circ} 31^{\prime} \mathrm{N}, 4^{\circ} 40^{\prime} \mathrm{E}\right)$. Asa River is the major water body in Ilorin, its course enters the southern end of the industrial estate from Asa Dam and it runs northwards through residential and commercial areas of Ilorin city. A scaled geographical map of the course of Asa River showing the study area and sampling points is shown in Figure 1. Apart from the containment of industrial effluents from several manufacturing plants within the estate, the river also serves as a recipient of domestic (sewage) wastes and agricultural waste run offs along the bank of the river. Along the area of the river segment are shopping complexes, a hospital, banks, a car park and a mini market for the sale of fresh vegetables and fish.

\subsection{Water Sampling}

Grab samples of water were taken from four different points-Ap, Bp, Cp and Dp-on the Asa River segment at the Unity Road bridge in Ilorin: points Ap and Bp are located at one side of the bridge and points $\mathrm{Cp}$ and $\mathrm{Dp}$ are at the other side of the bridge of the stream flowing northwards. Water sampling was carried out at weekly intervals for a period of 5 weeks between September and October, 2009. Samples were collected following the standard sampling guidelines and methods [11]. The samples were taken into pre-sterilized bottles kept in ice-boxes and transported immediately to the laboratory for physicochemical and bacteriological analyses. 


\subsection{Fish Sampling and Tissue Preparation}

Juvenile fish samples (100) of Clarias gariepinus (African catfish) were collected from the river section by the aid of a fisherman using conventional fish net traps in the early hours of the day. Samples of the same fish species were also collected from the Asa Dam reservoir water, a pollution-restricted reservoir, which was to serve as comparative control water during histological analysis. After dissection of fish samples in the laboratory, parts of the liver and intestine were carefully removed and prepared for histological studies [6].

Figure 1. A geographical map of the Asa River segment showing the study area and sampling points.

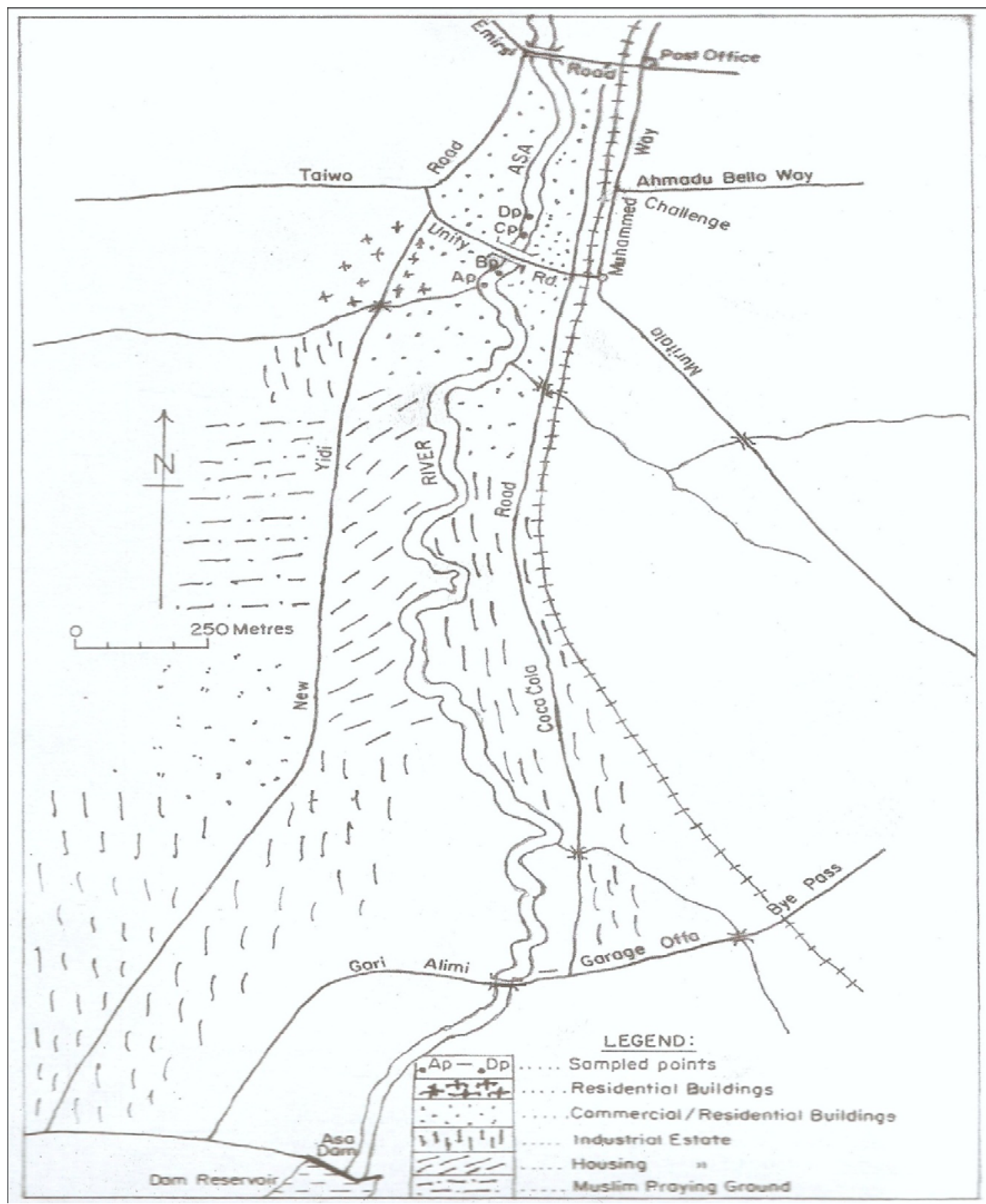




\subsection{Physico-Chemical Analysis}

The collected river water samples were analysed in the laboratory for $\mathrm{pH}$, temperature, total dissolved solids (TDS), total suspended solids (TSS), biochemical oxygen demand (BOD) and chemical oxygen demand (COD) per standard methods [12,22]. The $\mathrm{pH}$ of the samples was determined using a sensitive digital-electrode $\mathrm{pH}$ meter (Metrohm 632). The temperature of each sample collected was measured on-site with the use of a mercury bulb thermometer. The TDS and TSS of water samples were determined by the filtration and evaporation method while BOD and COD were determined using the alkaline-azide modification of Wrinkler's titration method [22].

\subsection{Bacteriological Analysis}

Quantitative bacteriological analysis of the water samples were carried out by using standard plate count (SPC) to enumerate total heterotrophic bacteria (TH) and using the membrane filtration (MF) method to enumerate total coliforms (TC) and total thermotolerant coliforms (TTC) [11,12]. Total coliforms and total thermotolerant coliforms were detected and quantified with the use of Eosin methylene blue (EMB) agar and their incubation at $37^{\circ} \mathrm{C}$ and $44.5^{\circ} \mathrm{C}$ respectively. Their counts were expressed in $\mathrm{cfu} / 100 \mathrm{~mL}$ of the water. The $\mathrm{IMViC}$ and other biochemical tests including production of greenish metallic sheen on the EMB agar plates were used to confirm and identify Escherichia coli $[23,24]$.

\subsection{Histological Investigations}

Specimens prepared for histological examination are from liver and intestine of juvenile Clarias gariepinus fish samples collected from both the test Asa River segment and the control Asa Dam water. The histological examination was done using the standard tissue examination techniques $[6,23,25]$.

\subsubsection{Examination for Alteration in General Tissue Structure}

Fixation of the specimens (tissues of liver and intestine) was done in 10\% neutral-buffered formalin for 72 hours. After fixing, the tissues were dehydrated by treating with ascending grades of alcohol solutions ( $70 \%$ to absolute). The tissues were then cleared in xylene, impregnated with molten paraffin wax and embedded in paraffin wax using embedding moulds which confer rigidity to the pieces of tissue for easy cutting of sections [6,25].

\subsubsection{Sectioning}

Sections were cut with the use of Leica Rotary Microtome to section thickness of $4 \mu \mathrm{m}$ from the paraffin wax blocks. The cut sections were placed onto $20 \%$ alcohol on a large slide, from where they were gently floated on water bath preheated to about $45{ }^{\circ} \mathrm{C}$, after which they were picked from water and mounted on clean grease-free microscope slides. Slides with sections were dried for about 30 minutes before staining. 


\subsubsection{Haematoxylin and Eosin ( $\mathrm{H}$ and $\mathrm{E})$ Staining for General Tissue Structure}

Haematoxylin and eosin staining were done as described elsewhere [25]. The cut-out sections were dewaxed in xylene and hydrated through descending grade of alcohol (absolute- $80 \%-70 \%$ water). The slides were stained in Harris haematoxylin for 10 minutes and then rinsed in water. The slides were dipped in $1 \% \mathrm{HCl}$ in $70 \%$ alcohol for 1 minute for differentiation and then rinsed in water. Blueing was done for 10 minutes in tap water after which counterstaining was done with $1 \%$ eosin for 1 minute. The slides were then rinsed in water, dehydrated, cleared and mounted for examination on the microscope followed by photomicrography.

\subsubsection{Examination of Bacterial Density in Tissues}

Demonstration of bacteria in the fish tissues was done using special staining by gram's staining modifications $[23,25]$. Thin sections of only the liver and intestine tissues of the fishes from both the test river water and control water were stained by special gram's staining method for bacterial examination.

\subsection{Statistical Analysis}

The data obtained was subjected to descriptive statistics using Mean and Standard Error of mean. Also, analysis of variance (ANOVA) test under Completely Randomized Design (CRD) was carried out while Duncan Multiple Range Test (DMRT) was used to test for the means that are significantly different from the other, which are presented by alphabets in superscripts in the tables presented.

\section{Results}

The results of the mean values of the physicochemical parameters of the water samples from the four sampling points on the river segment are presented in Table 1 while Figures $2-4$ display the variations in $\mathrm{pH}$ and temperature values; BOD and COD contents; and the TSS and TDS contents of the water samples, respectively, measured for a five-week period. The mean $\mathrm{pH}$ varied between 6.2 and 6.43 (Table 1 and Figure 2). The mean temperature of the water at different sampling points ranged from $24.5{ }^{\circ} \mathrm{C}$ to $25.3{ }^{\circ} \mathrm{C}$ (Table 1), while the temperature in weeks ranged from $24.3{ }^{\circ} \mathrm{C}$ to $25.8{ }^{\circ} \mathrm{C}$ (Figure 2). The mean values of the total suspended solids (TSS) and total dissolved solids (TDS) range from 766.60 to $1,498.60 \mathrm{mg} / \mathrm{L}$ and 704.60 to $1,799.80 \mathrm{mg} / \mathrm{L}$ respectively. The lowest values of both TSS and TDS were recorded at the sampling point $\mathrm{Cp}$.

The mean values of the chemical oxygen demand (COD) oscillated between $23.20 \mathrm{mg} / \mathrm{L}$ to $58.40 \mathrm{mg} / \mathrm{L}$ and also between $5.00 \mathrm{mg} / \mathrm{L}$ and $46.50 \mathrm{mg} / \mathrm{L}$ for the samples taken along the sampling points and over the weeks respectively (Table 1 and Figure 3). The COD values were remarkably high across the weeks with the exception of week 1 (Figure 3). The mean BOD values ranged from $6.48 \mathrm{mg} / \mathrm{L}$ at point $\mathrm{Dp}$ to $14.00 \mathrm{mg} / \mathrm{L}$ at point Ap. There was a consistent decrease in the BOD values along the sampling points from Ap to Dp (Table 1). The BOD across the weeks was highest in week 1 and lowest in week 2 with the values of $24.85 \mathrm{mg} / \mathrm{L}$ and $6.80 \mathrm{mg} / \mathrm{L}$ respectively (Figure 3). 
Table 1. Physicochemical properties of water samples taken at different points from Asa River Segment.

\begin{tabular}{ccccc}
\hline \multirow{2}{*}{ Parameter measured } & \multicolumn{4}{c}{ Sampling Points } \\
\cline { 2 - 6 } pH & $\mathbf{A}_{\mathbf{p}}$ (point 1) & $\mathbf{B}_{\mathbf{p}}$ (point 2) & $\mathbf{C}_{\mathbf{p}}$ (point 3) & $\mathbf{D}_{\mathbf{p}}$ (point 4) \\
\hline Temp. ( $\left.{ }^{\circ} \mathrm{C}\right)$ & $6.43 \pm 0.25^{\mathrm{a}}$ & $6.32 \pm 0.28^{\mathrm{a}}$ & $6.33 \pm 0.30^{\mathrm{a}}$ & $6.32^{\mathrm{a}} \pm 0.26^{\mathrm{a}}$ \\
TSS (mg/L) & $25.20 \pm 0.56^{\mathrm{a}}$ & $24.50 \pm 0.22^{\mathrm{a}}$ & $24.90 \pm 0.46^{\mathrm{a}}$ & $25.30 \pm 0.25^{\mathrm{a}}$ \\
TDS (mg/L) & $1,163.40 \pm 242.23^{\mathrm{b}}$ & $993.40 \pm 267.81^{\mathrm{b}}$ & $766.60 \pm 347.47^{\mathrm{b}}$ & $1,498.60 \pm 627.78^{\mathrm{b}}$ \\
COD (mg/L) & $1,201.40 \pm 308.14^{\mathrm{b}}$ & $1,799.80 \pm 1072.71^{\mathrm{b}}$ & $704.60 \pm 231.53^{\mathrm{b}}$ & $754.60 \pm 198.71^{\mathrm{a}}$ \\
BOD (mg/L) & $33.60 \pm 7.78^{\mathrm{a}}$ & $58.40 \pm 13.21^{\mathrm{a}}$ & $27.20 \pm 5.12^{\mathrm{a}}$ & $23.20 \pm 5.43^{\mathrm{a}}$ \\
\hline
\end{tabular}

Values are presented as Mean $\pm \operatorname{SEM}(n=5)$.

All groups are compared to each other at $\mathrm{P}<0.05$. Values with different superscripts along the same column are statistically different from each other.

Figure 2. Temporal variations in $\mathrm{pH}$ and Temperature values of water samples from Asa river measured over a five-week period.

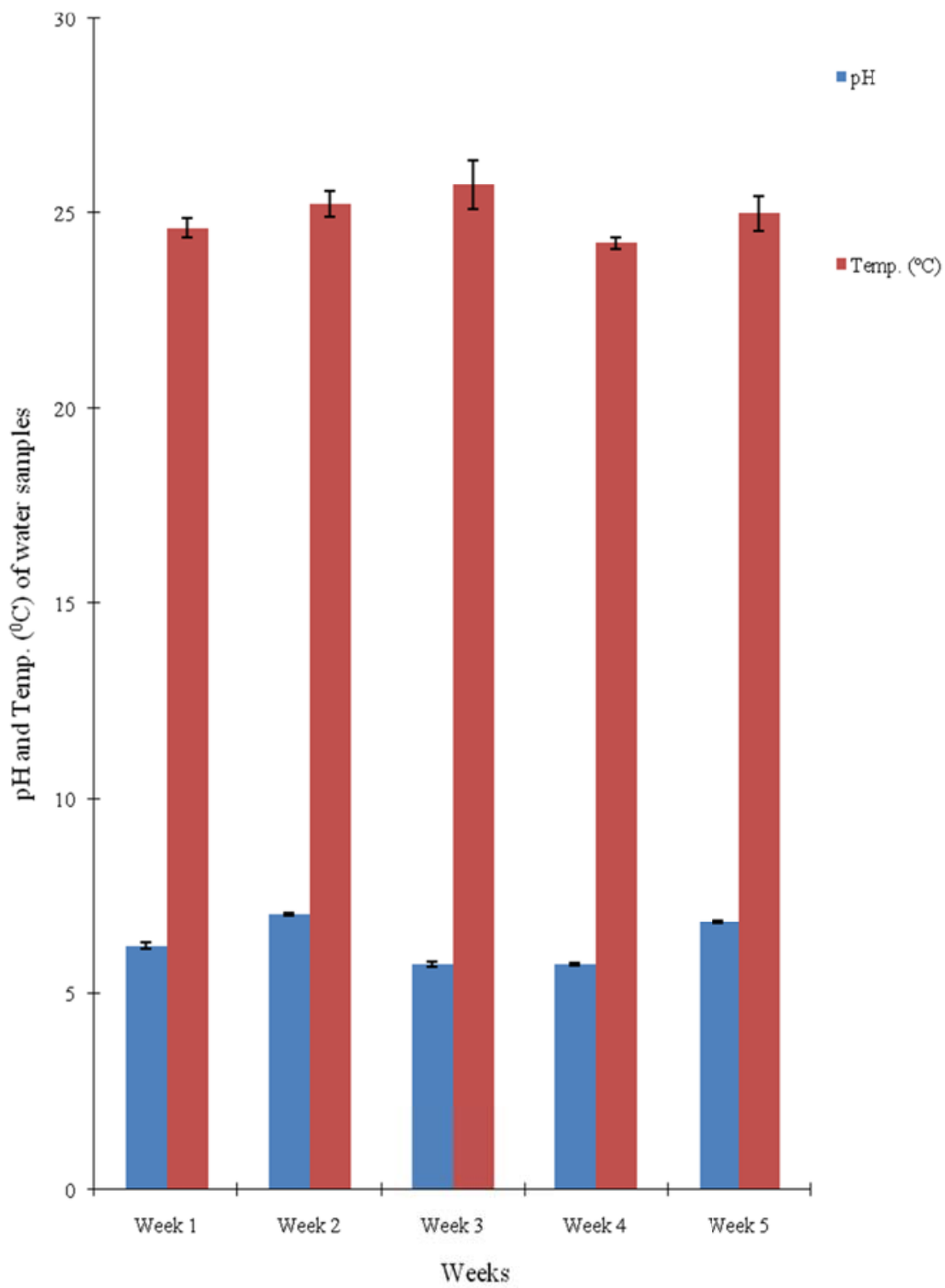


Figure 3. Temporal variations in COD and BOD contents of water samples from Asa river segment measured over a five-week period.

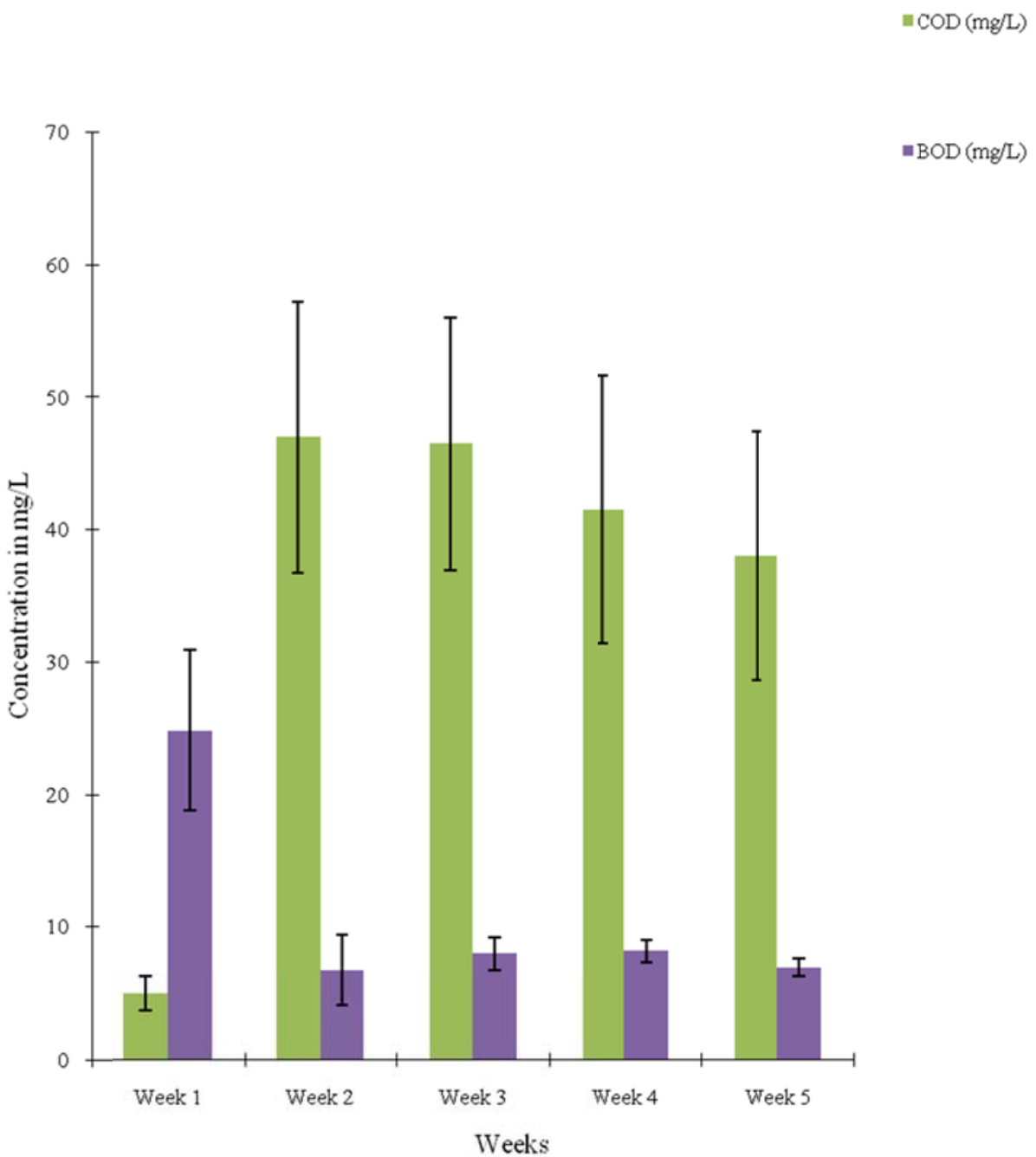

The mean total viable count of the total heterotrophic bacteria $(\mathrm{TH})$ at $37^{\circ} \mathrm{C}$, total coliforms (TC) and total thermotolerant (faecal) coliforms (TTC) of the water samples from different sampling points are presented in Table 2. The mean TH, TC and TTC of the water samples of Asa River segment over the five-week period are presented in Table 3 . The TH was highest at point Cp with $1.79 \times 10^{4} \mathrm{cfu} / \mathrm{mL}$ and lowest at point Dp with $1.09 \times 10^{4} \mathrm{cfu} / \mathrm{mL}$ (Table 2). The TH varied within the weeks as it oscillated between $4.70 \times 10^{3} \mathrm{cfu} / \mathrm{mL}$ in week 5 and $1.84 \times 10^{4} \mathrm{cfu} / \mathrm{mL}$ in week 2 (Table 3 ). The total heterotrophic count (TH) obtained in week 5 was significantly low and statistically different $(p<0.05)$ from the values obtained in the first four weeks. (Table 3). The total coliform count (TC) was relatively high and temporally varied as the values oscillated from $2.32 \times 10^{3} \mathrm{cfu} / 100 \mathrm{~mL}$ in week 5 to $6.20 \times 10^{3} \mathrm{cfu} / 100 \mathrm{~mL}$ in week 3 (Table 3 ). Total coliform count varied spatially and was generally high as it ranged from $3.56 \times 10^{3} \mathrm{cfu} / 100 \mathrm{~mL}$ to $5.24 \times 10^{3} \mathrm{cfu} / 100 \mathrm{~mL}$. An alarming high mean TC count was obtained in point $\mathrm{Cp}$ (Table 2). The total thermotolerant coliform count (TTC) ranged from $1.24 \times 10^{3} \mathrm{cfu} / 100 \mathrm{~mL}$ in week 5 to $4.80 \times 10^{3} \mathrm{cfu} / 100 \mathrm{~mL}$ in week 3 . The highest TTC along different sampling points was also recorded at point $\mathrm{Cp}$ with $3.22 \times 10^{3} \mathrm{cfu} / 100 \mathrm{~mL}$ as observed with the total coliform count of the same point. The TTC values were all relatively higher than the recommended limit for river water quality [26]. 
Figure 4. Temporal variations in TSS and TDS contents of water samples from Asa river measured over a five-week period.

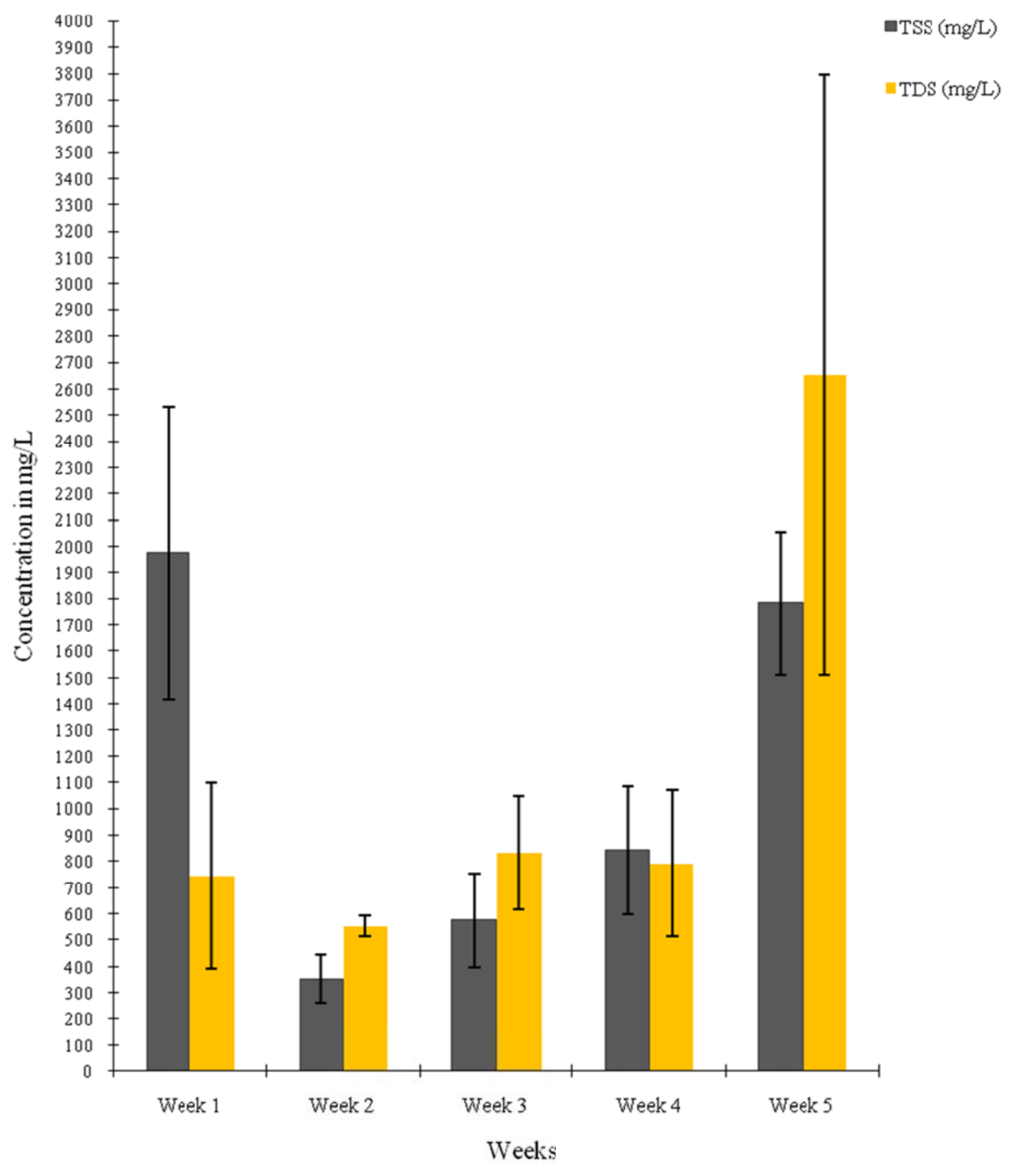

The percentage and ratio of mean total thermotolerant coliform count (TTC) to mean total coliform count (TC) was presented in Table 4. The TTC: TC percentages were all above $50 \%$ showing that more than half of the total coliforms are thermotolerant or are of faecal origin. The results of the physicochemical and bacteriological analysis of the Asa Dam water (control site) conformed to the limits of the WHO recommended regulatory standard for aquatic environments (data not shown). 
Table 2. Mean Total Heterotrophic, Total Coliform and Total Thermotolerant Coliform counts of the water samples from four sampling points on Asa River Segment.

\begin{tabular}{|c|c|c|c|c|}
\hline $\begin{array}{c}\text { Sampling } \\
\text { Points }\end{array}$ & $\begin{array}{c}\text { Total Heterotrophic } \\
\text { count (TH) } \\
(\mathbf{c f u} / \mathbf{m L})\end{array}$ & $\begin{array}{l}\text { Total Coliform count } \\
\text { (TC) } \\
(\mathbf{c f u} / \mathbf{1 0 0 m L})\end{array}$ & $\begin{array}{c}\text { Total Thermotolerant } \\
\text { Coliform count (TTC) } \\
\text { (cfu/100mL) }\end{array}$ & $\begin{array}{c}\text { Freshwater Quality } \\
\text { Standard Limit } \\
\text { (Faecal coliforms } \\
\text { per } 100 \text { mL) * }\end{array}$ \\
\hline$A_{p}$ (point 1) & $1.24 \times 10^{4} \pm 2,891.27^{\mathrm{a}}$ & $3.56 \times 10^{3} \pm 844.16^{a}$ & $2.99 \times 10^{3} \pm 767.03^{a}$ & 200 \\
\hline$B_{p}$ (point 2) & $1.24 \times 10^{4} \pm 3,414.67^{\mathrm{a}}$ & $4.50 \times 10^{3} \pm 804.36^{\mathrm{a}}$ & $2.49 \times 10^{3} \pm 641.57^{\mathrm{a}}$ & 200 \\
\hline$C_{p}$ (point 3) & $1.79 \times 10^{4} \pm 6,615.26^{a}$ & $5.24 \times 10^{3} \pm 1,088.39^{a}$ & $3.22 \times 10^{3} \pm 701.00^{\mathrm{a}}$ & 200 \\
\hline$D_{p}$ (point 4) & $1.09 \times 10^{4} \pm 2,309.46^{\mathrm{a}}$ & $3.84 \times 10^{3} \pm 946.89^{\mathrm{a}}$ & $2.88 \times 10^{3} \pm 876.58^{a}$ & 200 \\
\hline
\end{tabular}

* Source: USEPA [26].

Values are presented as Mean $\pm \operatorname{SEM}(n=5)$.

All groups are compared to each other at $\mathrm{P}<0.05$. Values with the same superscripts along the same column are not statistically different from each other.

Table 3. Mean Total Heterotrophic, Total Coliform and Total Thermotolerant Coliform counts of the water samples taken for a five-week period from Asa River.

\begin{tabular}{ccccc}
\hline $\begin{array}{c}\text { Sampling } \\
\text { Period }\end{array}$ & $\begin{array}{c}\text { Total Heterotrophic } \\
\text { count (TH) } \\
\mathbf{( c f u} / \mathbf{m L})\end{array}$ & $\begin{array}{c}\text { Total Coliform } \\
\text { count } \mathbf{( T C )} \\
\mathbf{( c f u} / \mathbf{1 0 0 m L})\end{array}$ & $\begin{array}{c}\text { Total Thermotolerant } \\
\text { Coliform count (TTC) } \\
\mathbf{( c f u / 1 0 0 m L )}\end{array}$ & $\begin{array}{c}\text { Freshwater Quality } \\
\text { Standard Limit } \\
\text { (Faecal coliforms } \\
\text { per 100 mL) * }\end{array}$ \\
\hline Week 1 & $1.12 \times 10^{4} \pm 2,015.564^{\mathrm{ab}}$ & $3.77 \times 10^{3} \pm 311.92^{\mathrm{a}}$ & $2.67 \times 10^{3} \pm 661.28^{\mathrm{ab}}$ & 200 \\
& & & & \\
Week 2 & $1.84 \times 10^{4} \pm 3084.47^{\mathrm{b}}$ & $6.07 \times 10^{3} \pm 878.80^{\mathrm{b}}$ & $3.80 \times 10^{3} \pm 435.89^{\mathrm{bc}}$ & 200 \\
Week 3 & $1.50 \times 10^{4} \pm 408.25^{\mathrm{ab}}$ & $6.20 \times 10^{3} \pm 906.46^{\mathrm{b}}$ & $4.80 \times 10^{3} \pm 624.50^{\mathrm{c}}$ & 200 \\
Week 4 & $1.77 \times 10^{4} \pm 8,410.06^{\mathrm{ab}}$ & $3.05 \times 10^{3} \pm 723.99^{\mathrm{a}}$ & $1.96 \times 10^{3} \pm 366.59^{\mathrm{a}}$ & 200 \\
Week 5 & $4.70 \times 10^{3} \pm 624.50^{\mathrm{a}}$ & $2.32 \times 10^{3} \pm 232.29^{\mathrm{a}}$ & $1.24 \times 10^{3} \pm 189.80^{\mathrm{a}}$ & 200 \\
\hline
\end{tabular}

* Source: USEPA [26].

Values are presented as Mean $\pm \operatorname{SEM}(n=4)$.

All groups are compared to each other at $\mathrm{P}<0.05$. Values with different superscripts along the same column are statistically different from each other.

Table 4. Percentage and ratio of thermotolerant (faecal) coliforms to total coliforms (TTC:TC) of water samples over a period of 5 weeks.

\begin{tabular}{ccccc}
\hline $\begin{array}{c}\text { Sampling } \\
\text { Period }\end{array}$ & $\begin{array}{c}\text { Mean total } \\
\text { coliform } \\
\text { counts (TC) } \\
\text { (cfu/100mL) }\end{array}$ & $\begin{array}{c}\text { Mean total } \\
\text { thermotolerant } \\
\text { coliform } \\
\text { counts (TTC) } \\
\text { (cfu/100mL) }\end{array}$ & $\begin{array}{c}\text { Percentage } \\
\text { TTC in TC } \\
\mathbf{( \% )}\end{array}$ & $\begin{array}{c}\text { Faecal } \\
\text { Coliform } \\
\text { Index (TTC: } \\
\text { TC Ratio) }\end{array}$ \\
\hline Week 1 & $3.77 \times 10^{3}$ & $2.67 \times 10^{3}$ & 70.86 & 0.71 \\
Week 2 & $6.07 \times 10^{3}$ & $3.80 \times 10^{3}$ & 62.55 & 0.63 \\
Week 3 & $6.20 \times 10^{3}$ & $4.80 \times 10^{3}$ & 77.42 & 0.77 \\
Week 4 & $3.05 \times 10^{3}$ & $1.96 \times 10^{3}$ & 64.51 & 0.65 \\
Week 5 & $2.32 \times 10^{3}$ & $1.24 \times 10^{3}$ & 53.55 & 0.54 \\
\hline
\end{tabular}


Photomicrographs of representative slides showing histological structures of stained tissue sections of the fish liver and intestine are presented in Figures 5 and 6, while the photomicrographs showing the differentiated bacterial population present in the liver and intestinal tissues are presented in Figures 7 and 8 .

Liver: The histological sections of the liver tissues structures of Clarias gariepinus from Asa River and Asa Dam water (control site) as shown in Figure 5(a,b) respectively. The hepatocytes of both sections are normal. They are mostly binucleated and multinucleated. They are normochromic at higher magnification $(400 \times)$. The nucleoli are clearly seen and there are few areas of sinusoids containing erythrocytes. The fish liver tissues from the Asa River and Asa Dam water (control site) were comparatively normal with no visible alterations.

Figure 5. (a) Histological structures of the liver of Clarias gariepinus caught from Asa River segment; (b) Histological structures of the liver of Clarias gariepinus caught from Asa Dam water (Control). Plates showed no distinct histological damage in the liver of the test fish compared to the control (at magnification 100×). Arrows showed the binucleated hepatocytes (Q), the clear portal venules (PV) and the sinusoidal lining cells (SC).

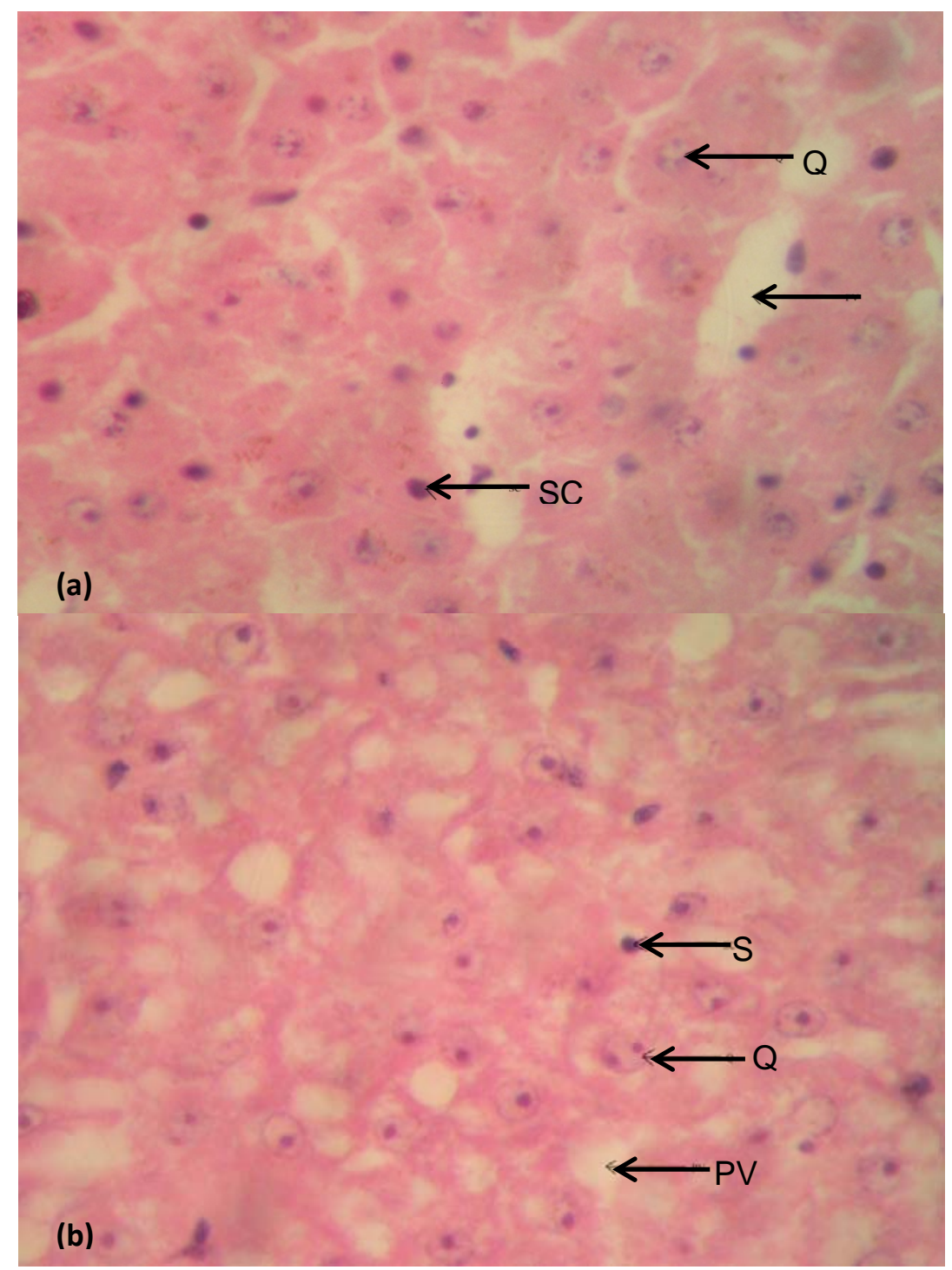


Intestine: The histological sections of the intestine tissues structures of Clarias gariepinus from Asa River and Asa Dam water (control site) as shown in Figure 6(a,b), respectively. The digestive tract sections were well stained with distinct normal layers from mucosa to the serosa. The mucosa (columnar epithelium and lamina propia), submucosa (loose connective tissue), muscularis (circularis and longitudinale) and serosa (mesothelium) are clearly seen with higher magnification $(100 \times)$. Slides of Figure 6(a,b) are from the pyloric caeca. Comparatively, they are the same with no visible alterations.

Figure 6. (a) Histological structures of the intestine of Clarias gariepinus caught from Asa River segment; (b) Histological structures of the intestine of Clarias gariepinus caught from Asa Dam water (control). Plates showed no distinct histological damage in the intestine of test fish compared to the control (at magnification 100×). Arrows showed the distinct layers of the intestinal Mucosa (Epithelium, E and lamina propia, L), the Submucosa (SM), the Muscularis (MM) and the Serosa (Sr).

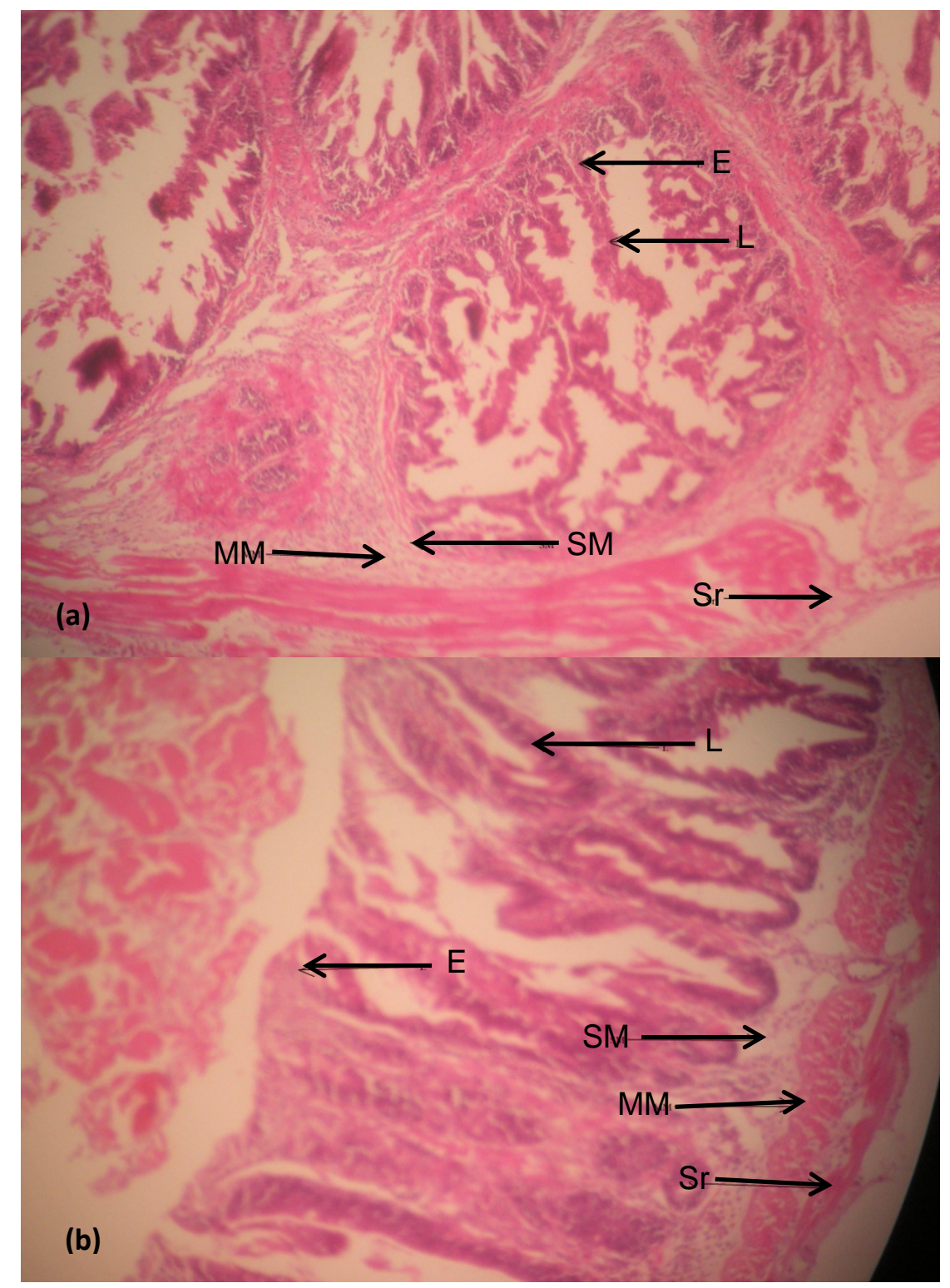


Bacteria in Liver: The photomicrographs of the differentiated bacterial cells present in the liver tissues of Clarias gariepinus from the test Asa River and the control Dam water as shown in Figure 7(a,b), respectively. Blue-black shades of cells denote the Gram-positive bacteria while shades of red colour denote Gram-negative bacteria and hepatocytes. Figure 7(a) shows numerous Gram-positive and Gram-negative cells which are concentrated and dispersed in some areas within the tissue section. The Gram-negative cells are more densely populated in the liver than the Gram-positive cells as indicated by more red shades on the plate. Figure 7(b) reveals purely dispersed but scanty Gram-negative and Gram-positive cells. However, Figure 7(a) indicates a comparatively higher microbial load/density in the liver than that seen in Figure 7(b).

Figure 7. (a) Examination of bacteria in liver tissues of Clarias gariepinus obtained from Asa River segment; (b) Examination of Bacteria in liver tissues of Clarias gariepinus obtained from Asa Dam water. Plates showed a higher bacterial density in the liver tissues of the test fish than in the control (at magnification 400×). Arrows showed the Gram-negative bacteria (shades of red), few Gram-positive bacteria (blue-black shades) and hepatocytes (h) on the photomicrographs.

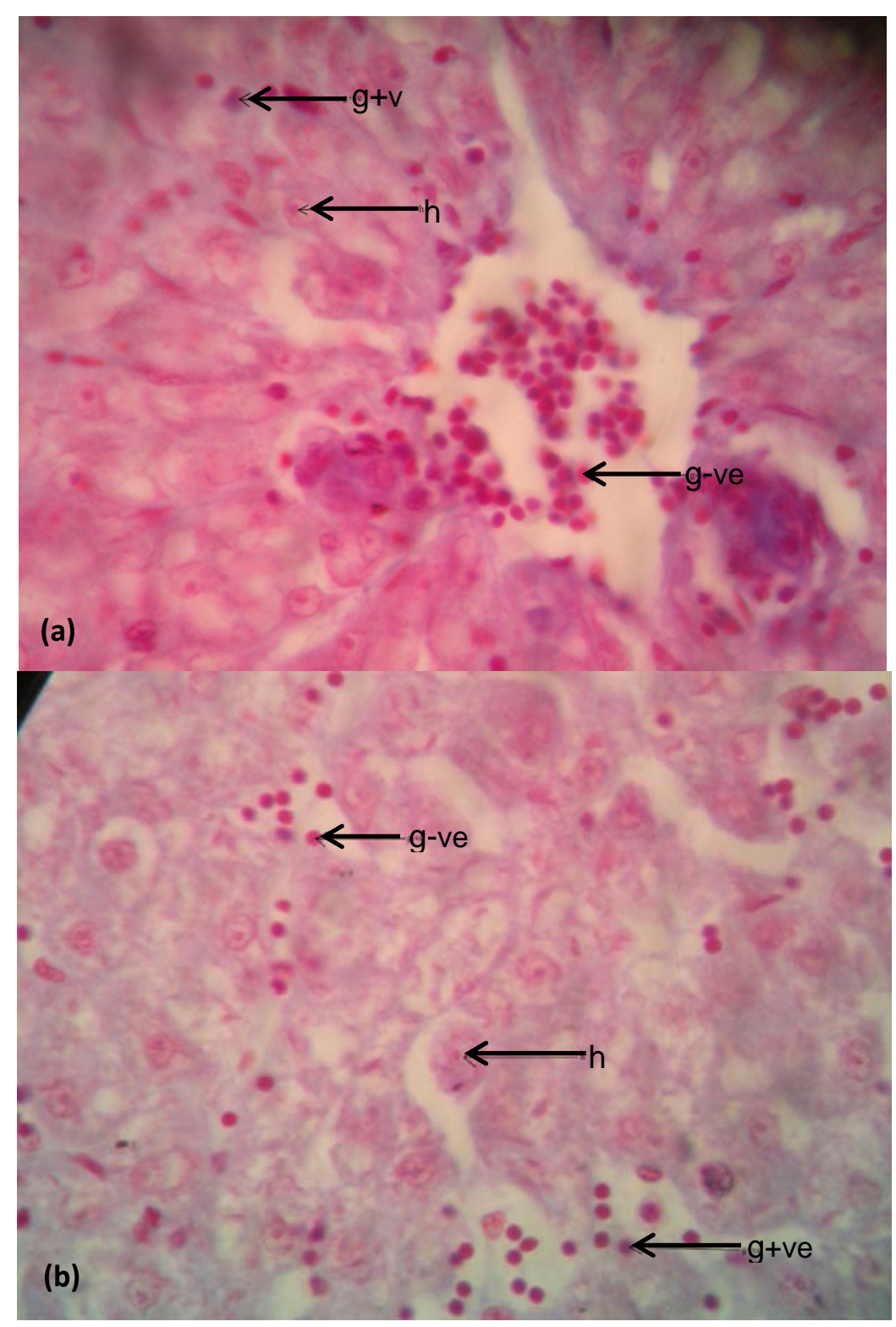


Bacteria in Intestine: The differentiated bacteria cells present in the intestinal tissue sections of Clarias gariepinus from the test Asa River and the control Asa Dam water as shown in Figure 8(a,b), respectively. There was a small distinction with a little increase in the bacterial population in the intestine of Clarias gariepinus from Asa River over the bacterial population in the intestine of Clarias gariepinus from the Asa Dam water. Figure 8(a) shows concentrated Gram-negative and Gram-positive bacteria in the digestive tract. Figure 8(b) also shows concentrated Gram-negative cells but scanty gram-positive cells.

Figure 8. (a) Examination of bacteria in the intestinal tracts of Clarias gariepinus obtained from Asa River segment; (b) Examination of Bacteria in the intestinal tracts of Clarias gariepinus obtained from Asa Dam water. Plates showed a small increase in the bacterial density in the intestine of test fish compared to the control (at magnification $400 \times$ ). Arrows showed the numerous Gram-negative bacteria (in red shades (g-ve) and few Gram-positive bacteria [blue-black shades $(\mathrm{g}+\mathrm{ve})]$ on the photomicrographs.

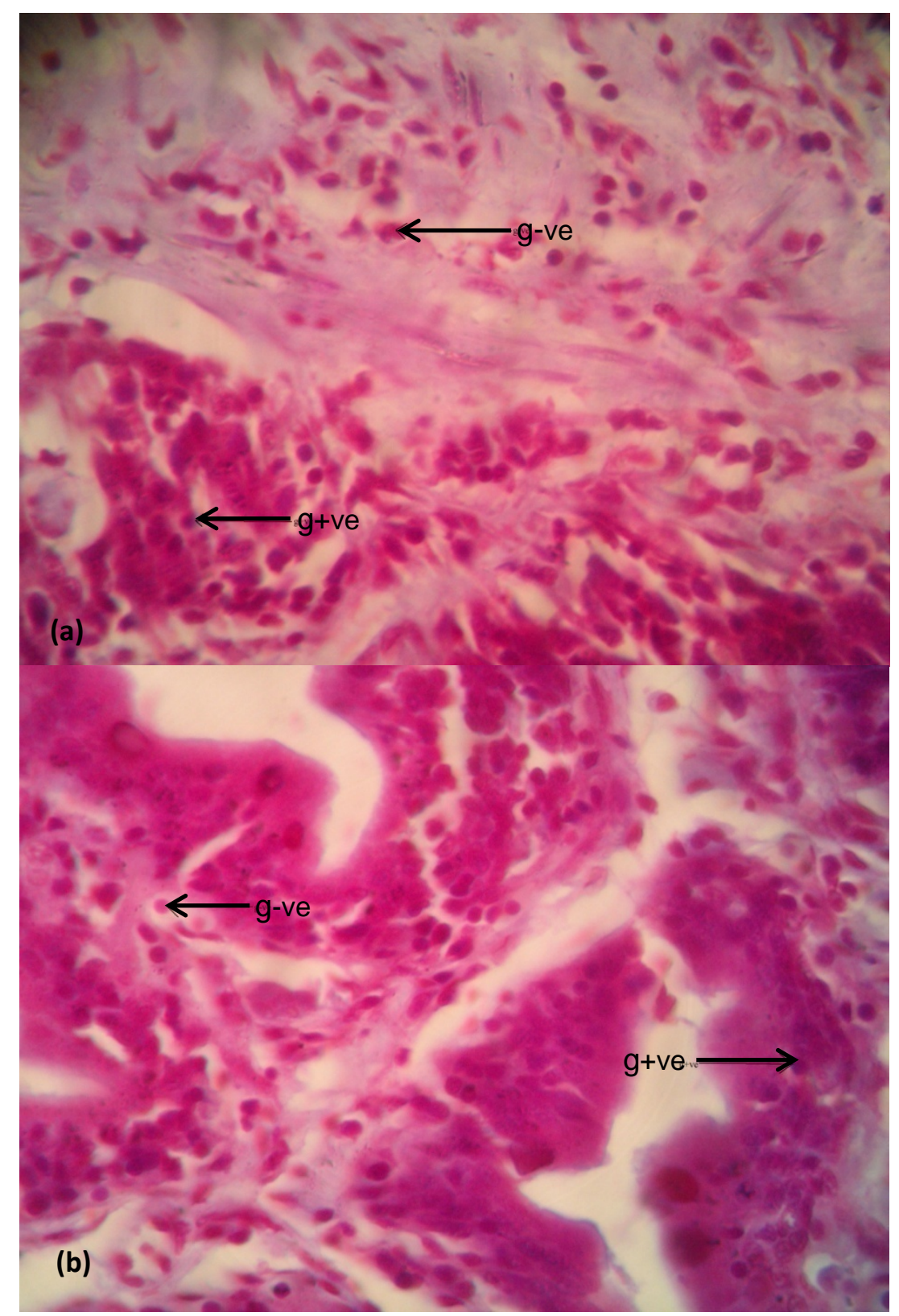




\section{Discussion}

Water quality is neither a static condition of a system, nor can it be defined by the measurement of only one parameter. There is a range of chemical, physical and biological components that affect water quality. These variables provide general indication of water pollution, whereas others enable a direct tracking of pollution sources [1].

The $\mathrm{pH}$ of water samples collected in time and space from the river section were slightly below neutral (Table 1 and Figure 2) and these values fall within the accepted range of 6.0-8.5 indicative of good water quality $[1,27,28]$. The mean temperature values of the water samples are not statistically different from each other $(p<0.05)$ and also fall within the normal temperature range supportive of good surface water quality which is $0{ }^{\circ} \mathrm{C}$ to $30{ }^{\circ} \mathrm{C}$ [28]. Hence, the temperature of the water from Asa River could not be implicated as influencing the observed variations in the bacterial population as well as in other physicochemical parameters. However, the observed range of the temperature allows for optimum proliferation of most of the bacteria isolated from the water samples. Enterobacteriaceae are mesophiles most of which grows optimally at temperature range of $20^{\circ} \mathrm{C}$ and $32{ }^{\circ} \mathrm{C}$ [29].

The significantly high total suspended solids (TSS) and total dissolved solids (TDS) of the water $(p<0.05)$ are implicative of a high level of pollution of the Asa River when compared to the WHO standard limit for good water quality which is $500 \mathrm{mg} / \mathrm{L}$ for TSS and 1,000 mg/L for TDS [28]. TSS and TDS are indicative of materials carried in suspension and solid respectively [30]. Suspended solids in streams are often as a result of sediments carried by the water whose source includes natural and anthropogenic (human) activities in the water shed, such as natural or excessive soil erosion from agriculture, forestry or construction, urban run-off, industrial effluents or phytoplankton growth [31]. Suspended solids content was also reported to be directly proportional to instantaneous discharge of effluents measured in the Yellow River in China [1]. The high TSS and TDS content values of the water show significant direct relationships to the high bacterial population obtained from the water samples.

The significant decrease in the TSS and TDS content of water samples collected at point Cp, the point which tends downwards and northwards away from points Ap and Bp could be linked to the observed correspondingly lowest count of the total heterotrophic bacteria enumerated at the same point $\mathrm{Cp}$ of interest. This observed decrease could be linked to the effect of self-purification process at the flowing stream which could reduce the microbial population.

The high BOD and very high COD values are indicative of the presence of organic and inorganic pollutants, respectively. The mean BOD values of all exceeded the recommended maximum allowable concentration (RMC) set by the European Union for good quality water for fisheries and other aquatic life which is $3.0-6.0 \mathrm{mg} / \mathrm{L}$ [28]. Unpolluted waters typically have BOD values of $2 \mathrm{mg} / \mathrm{L}$ or less, whereas those receiving wastewaters may have values up to $10 \mathrm{mg} / \mathrm{L}$ or more [28]. It was reported that these parameters i.e., BOD and COD are responsible for odour and taste [32]. The COD usually includes all, or most of the BOD as well as some other chemical demands. The significantly high mean COD values also exceeded the acceptable concentrations for unpolluted surface water quality which is $20 \mathrm{mg} / \mathrm{L}$ or less. It however falls within the range of polluted waters $(20-200 \mathrm{mg} / \mathrm{L})$ [28].

The high BOD and COD values may be due to the discharge of untreated or incompletely treated industrial effluents into the river from the various manufacturing plants in the industrial estate such as 
Global Soaps and Detergents, Seven-Up Bottling Company, Nigeria Bottling Company (Coca-Cola), Dangote Flour Mills, Rajrab Pharmaceutical Company, etc. The BOD values are high probably due to discharge of domestic wastes especially defecation activities and poorly executed agricultural activities near the river banks which was observed during survey of study site. The downward trend in the BOD values along the sampling points Ap to $\mathrm{Dp}$ (Table 1) which goes in a northward direction with the river flow indicates a decrease in the organic pollution level. This might be due to the self-purification process in the river. The self-purification process in a river is a phenomenon that has been noted in waters contaminated by sewage. It is a complex process running in many stages [33-35].

A faecal coliform index obtained by a ratio of faecal coliforms to total coliforms, has been proposed and recommended by USEPA instead of the formally used total coliform index for evaluating the microbiological suitability of freshwaters for recreational uses. The proposed maximum acceptable limit was 200 faecal coliforms per $100 \mathrm{~mL}$ and $126 \mathrm{E}$. coli per $100 \mathrm{~mL}$ [26]. This preference was because faecal coliforms were more faecal-specific and less subject to variation than total coliforms which were greatly influenced by storm water run-off. It has also been found that, usually, more than 95 percent of thermotolerant coliforms isolated from water are the gut organism Escherichia coli, the presence of which is definitive proof of faecal contamination [36].

The alarming high number of total coliforms and thermotolerant (faecal) colifoms per $100 \mathrm{~mL}$ obtained from the water samples, which exceeds at least ten times the recommended limit, indicates high level of faecal pollution of the river water which potentially poses a high health risk for recreational purposes, let alone for drinking purpose. This clearly implies that the organic pollution of the river is more of faecal pollution. It was reported in a previous study on the Ohio River at Dayton in the US that swimmers who swam in water with a median coliform density of 2,300 coliforms per $100 \mathrm{~mL}$ had an excess of gastrointestinal illness rate when compared to an expected rate calculated from the total study population [26]. It was posited that the total number of heterotrophic bacteria reflects the contamination extent by the easily decomposable organic matters, while the faecal coliform bacteria number gives an idea of the contamination size by faecal substance [37].

The ANOVA test showed that there are significant variations in the total coliform counts and the thermotolerant coliforms counts between weeks on all sampling points $(p<0.05)$. The variations might be due to climatic factors such as rainfall and changes in the anthropogenic activities during the period of analysis. The occurrence of irregular variations in coliform bacteria was congruent with the findings of [10] and [38]. In most circumstances, concentrations of the thermotolerant coliforms are directly related to that of $E$. coli. The presence of $E$. coli or thermotolerant coliform bacteria gives an indication of presumptive presence of water-borne pathogens [11,39].

The histological findings on the tissue structures of the four different parts of Clarias gariepinus collected from experimental Asa River section depicted no significant alterations or pathological effects in the livers and intestines when compared with those collected from the control Asa Dam water. This result does not corroborate with similar studies on fish species of Tilapia zillii and Solea vulgaris from Lake Qarun in Egypt which observed histological alterations in the muscles including vacuolar degeneration and aggregation of necrosis in gills and inflammatory cells in hepatocytes of liver tissues [6].

The observed histological alterations in the fishes studied in Lake Qarun was possible simply because the lake is a closed system which acts as a reservoir for agricultural and sewage drainage 
water and whose components are found to be polluted with heavy metals [40,41]. However, such alterations could not be found in the viscera of the studied fish species from Asa River being inhabitants of a flowing system and owing to the possibilities of pollution dilution and self-purification in the river. This would possibly reduce the bioaccumulation rate of the water pollutants in the tissues of the resident fish.

Previous toxicological evaluation studies on the Amilegbe segment of Asa River by haematological and enzyme studies of rats fed the polluted river water revealed marked haematological changes and effects on enzymes of the rat after a period of eight weeks [30]. This was achievable as it is a controlled environment outside the field. The results of the present study has not proven the histopathology of live indigenous fishes as an effective biomarker of in situ river pollution impact of non-point source pollution, though it has been for chronic exposure studies on specific metal concentrations [42-46].

Nevertheless, the high microbial load observed on the gram-stained histological slides of the fish liver and intestine (Figures 7 and 8) is in agreement with the results of the physicochemical and bacteriological evaluation of Asa River pollution and its impact on the aquatic life. There are comparative distinctions. The dense bacterial population observed in the fish intestine of both Asa River and the control water could be due to the enteric region of the fish. The increase in microbial load observed in the fish liver from Asa River when compared to the control reveals pollution effect in the fishes of the river.

The comparative study done between the catfish of the Asa Dam reservoir water (control) and the polluted Asa River segment revealed, by bacterial examination in the fish tissues observed through special staining, a comparatively significant alteration of the normal microbial flora of the catfish from the polluted river.

In his work, Strauss reported that invasion of fish flesh by pathogenic bacteria was very likely if the fish were reared in water containing over $10^{4}$ of faecal coliforms (Escherichia coli) and that high concentrations of pathogenic microorganisms might occur in the digestive tract and intraperitoneal fluid of the fish even at low numbers of indicatory bacteria [47]. The values pointed out in Strauss' work were within range with the values obtained in the bacteriological examination of Asa River water. These findings, however, render the microbiological quality of the fishes from the polluted river poor and unsafe for consumption.

\section{Conclusions}

This pollution impact study has proven that the downstream Asa River segment is indeed polluted. The study has been able to track the type of pollution to be more of faecal contamination by the evaluation of the bacteriological quality of the river water samples. Non-point sources of pollution which include the agricultural activities (pesticides and crop wastes) and domestic activities by the poorly planned settlers nearby the river as well as the point source discharge of industrial effluents along the industrial estate have been implicated to be causative to the poor quality of the river and its aquatic life.

This study has also shown that there were no significant tissue alterations observed during the comparative histological studies carried out on juvenile live samples of Clarias gariepinus caught 
from the polluted Asa River and the control Asa Dam water. However, this does not imply good quality of the aquatic life of the river as further investigation of the bacteria present in the fish tissues portrayed very high bacterial density in the tissues of Clarias gariepinus collected from the Asa River segment when compared to the tissues of Clarias gariepinus caught from the Asa Dam water. The implications of these findings may be that people dependent on this river water for domestic use including cooking, bathing, washing and even drinking or for agricultural uses like fishing and farming may be exposed to public health risks. Proper treatment is imperative for the river to be appropriate for potable, domestic and industrial purposes.

It is therefore recommended to coordinate different efforts at the level of the community dwellers and the government to rescue the downstream Asa River segment and its aquatic life from the current hazard-posing environmental problems.

\section{Conflict of Interest Statements}

The authors declare no conflict of interest.

\section{Acknowledgements}

This research was supported by the Senate Research Grant of the University of Ilorin and Post Doctoral Research Fellowship Grant from the University of Fort Hare, South Africa.

\section{References}

1. United Nations Environment Programme Global Environment Monitoring System/Water Programme. Water Quality for Ecosystem and Human Health; National Water Research Institute: Burlington, ON, Canada, 2000.

2. Stark, J.R.; Hanson, P.E.; Goldstein, R.M.; Fallon, J.D.; Fong, A.L.; Lee, K.E.; Kroening, S.E.; Andrews, W.J. Water Quality in the Upper Mississippi River Basin, Minnesota, Wisconsin, South Dakota, Iowa, and North Dakota, 1995-98; United States Geological Survey: Reston, VA, USA, 2001.

3. Kolawole, O.M.; Ajibola, T.B.; Osuolale, O.O. Bacteriological Investigation of a wastewater discharge run-off stream in Ilorin, Nigeria. J. Appl. Environ. Sci. 2008, 4, 33-37.

4. Koshy, M.; Nayar, T.V. Water quality aspects of River Pamba. Pollut. Res. 1999, 18, 501-510.

5. Hammer, M.J. Water and Wastewater Technology, 5th ed.; Practice-Hall Inc.: Upper Saddle River, NJ, USA, 2004; pp. 139-141.

6. Mohammed, F.A.S. Histopathological studies on Tilapia zilli and Solea vulgaris from lake Quran, Egypt. World J. Fish Mar. Sci. 2009, 1, 29-39.

7. Gerardi, M.H.; Zimmerman, M.C. Wastewater Pathogens; John Wiley \& Sons, Inc.: Hoboken, NJ, USA, 2005, pp. 3-4.

8. Adekunle, A.S.; Eniola, I.T.K. Industrial effluents on quality of segment of Asa River within an industrial estate in Ilorin, Nigeria. New York Sci. J. 2008, 1, 17-21. 
9. Maduka, H.C.C. Water Pollution and Man's Health in Environmental Degradation, Reclamation, Conservation and Pollution Control for the Rural Women and the Youths; Green Line Publishers: Ado Ekiti, Nigeria, 2004, pp.198-203.

10. Chandra, R.; Singh, S.; Raj, A. Seasonal bacteriological analysis of Gola River water contaminated with pulp paper mill waste in Uttaranchal, India. Environ. Monit. Assess. 2006, 118, 393-406.

11. World Health Organization (WHO). Guidelines for Drinking Water Quality: Surveillance and Control of Communities Supplies, 2nd ed.; WHO: Geneva, Switzerland, 1997; Volume 3.

12. American Public Health Association (APHA). Standard Methods for the Examination of Water and Wastewater, 15th ed.; APHA: Washington, DC, USA, 1981; pp. 85-99, 773-779, 786-828.

13. Brenner, K.P.; Rankin, C.C.; Roybal, Y.R., Jr.; Stelma, G.N.; Scarpino, P.V.; Dufour, A.P. New medium for the simultaneous detection of total coliforms and Escherichia coli in water. Appl. Environ. Microbiol. 1993, 59, 3534-3544.

14. Grant, M.A. A new membrane filtration medium for simultaneous detection and enumeration of Escherichia coli and total coliform. Appl. Environ. Microbiol. 1997, 63, 3526-3530.

15. Wester, P.W.; Canton, J.H. The usefulness of histopathology in aquatic toxicity studies. Comp. Biochem. Physiol. C 1991, 100, 115-117.

16. Thophon, S.; Kruatrachue, M.; Upathan, E.S.; Pokethitiyook, P.; Sahaphong, S.; Jarikhuan, S. Histopathological alterations of white seabass, Lates calcarifer in acute and subchronic cadmium exposure. Environ. Pollut. 2003,121, 307-320.

17. Camargo, M.M.P.; Martinez, C.B.R. Histopathology of gills, kidney and liver of a neotropical fish caged in an urban stream. Neotrop. Ichthyol. 2007, 5, 327-336.

18. Hinton, D.E.; Baumann, P.C.; Gardner, G.R.; Hawkins, W.E.; Hendricks, J.D.; Murchelano, R.A.; Okihiro, M.S. Histopathologic Biomarkers. In Biomarkers-Biochemical, Physiological and Histological Markers of Anthropogenic Stress; Hugget, R., Kimerle, R., Mehrle, P., Bergman, H., Eds.; Lewis Publishers: Boca Raton, FL, USA, 1992; pp.155-195.

19. Schwaiger, J.; Wanke, R.; Adam, S.; Pawert, M.; Honnen, W.; Triebskorn, R. The use of histopatological indicators to evaluate contaminant-related stress in fish. J. Aquat. Ecosyst. Stress Recov. 1997, 6, 75-86.

20. Teh, S.J.; Adams, S.M.; Hinton, D.E. Histopathological biomarkers in feral freshwater fish populations exposed to different types of contaminant stress. Aquat. Toxicol. 1997, 37, 51-70.

21. Eletta, O.A.; Adekola, F.A.; Aderanti, M.A. Assessment of Asa River: Impact of waste discharge from soft drink plant into Asa River, Ilorin. Nigerian J. Appl. Sci. Environ. Mgt. 2005, 9, 187-190.

22. Ademoroti, C.M.A. Standard Methods for Water and Effluents Analysis; Foludex Press Ltd.: Ibadan, Nigeria, 1996; pp. 1-49.

23. Ochei, J.O.; Kolhatkar, A.A. Medical Laboratory Science: Theory and Practice; Tata McGrawHill Publishing Company Ltd.: New Delhi, India, 2004; pp. 530-831.

24. Tang, Y.; Strattom, C.W. Advanced Techniques in Diagnostic Microbiology; Springer Science/ Business Media: New York, NY, USA, 2006; pp. 84-116.

25. Avwioro, O.G. Histochemistry and Tissue Pathology-Principles and Techniques, 1st ed.; Claverianum Centre: Ibadan, Nigeria, 2002, pp. 155-157, 214-218. 
26. United States Environmental Protection Agency (US EPA). Bacteriological Ambient Water Quality Criteria for Marine and Fresh Recreational Waters; Office of Water Regulations and Standards Division: Washington, DC, USA, 1986; pp. 1-60.

27. WHO. Drinking Water Guidelines: Bacteriological Parameters; WHO: Geneva, Switzerland, 2002; Volume 13.

28. Water Quality Assessments: A Guide to the Use of Biota, Sediments and Water in Environmental Monitoring, 2nd ed.; Chapman, D., Ed.; Chapman and Hall: London, UK, 1996.

29. Fransolet, G.; Villers, G.; Masschein, W.J. Influence of temperature on bacterial development in waters. Ozone Sci. 1985, 7, 205-227.

30. Oladiji, A.T.; Adeyemi, O.; Abiola, O.O. Toxicological evaluation of the surface water of Amilegbe River using rats. Niger. Soc. Exper. Biol. Biochem. 2004, 16, 94-101.

31. United States Environmental Protection Agency (US EPA). Volunteer Stream Monitoring: A Methods Manual; EPA 841-B-97-003; US EPA: Washington, DC, USA, 1997. Available online: http://www.epa.gov/owow/monitoring/volunteer/stream/ (accessed on 4 July 2006).

32. Lee, G.F.; Jones-Lee, A. Landfills and Groundwater Pollution Issue Dry Tomb vs. F/L Wet Cell. In Proceedings of Sardinia 93: Fourth International Landfill Symposium, Cagliari, Italy, 11-15 October 1993; pp. 1-10.

33. Droppo, I.G.; Ongley, E.D. Flocculation of suspended sediment in rivers of Southeastern, Canada. Water Res. 1994, 28, 1799-1809.

34. Hoch, B.; Berger, B.; Kavka, G.; Herndl, G.J. Remineralization of organic matter and degradation of the organic fraction of suspended solids in the River Danube. Aquatic Microb. Ecol. 1995, 9, 279-288.

35. Niemi, J.S.; Heitto, L.; Niemi, R.M.; Anttilahuhtinen, M.; Malin, V. Bacteriological purification of the Finninh River Kymi. Environ. Monit. Assess. 1997, 46, 241-253.

36. Water Quality Monitoring: A Practical Guide to the Design and Implementation of Freshwater Quality Studies and Monitoring Programmes; Bartram, J., Ballance, R., Eds.; Chapman and Hall: London, UK, 1996.

37. Donderski, W.; Wilk, W. Bacteriological studies of water and bottom sediments of the Vistula River between Wyszogrod and Torun. Pol. J. Environ. Stud. 2001, 11, 33-40.

38. Ramanibai, R. Seasonal and spatial abundance of pollution indicator bacteria in Buckingham canal madras. Indian J. Environ. Prot. 1996, 17, 110-114.

39. World Health Organization. Guidelines for Drinking Water Quality: Incorporating First Addendum, 3rd ed.; WHO: Geneva, Switzerland, 2006; Volume 1.

40. Mansour, S.A.; Sidky, M.M. Ecotoxicological studies: The first comparative study between Lake Garun and Wadi El-Rayan (Egypt), with respect to contamination of their major components. Food Chem. 2003, 82, 181-189.

41. Mohammed, F.A.; Gag, N.S. Environmental pollution-induced biochemical changes in tissues of Tilapia zillii, Solea vulgaris and Mugil capito from Lake Qarun, Egypt. Global Vet. 2008, 2, 327-336.

42. Secombes, C.J.; Fletcher, T.C.; White, A.; Costello, M.; Stagg, R.; Houlihan, D. Effects of sewage sludge on immune responses in the dab. Limanda mimanda. Aquat. Toxicol. 1992, 23, 217-220. 
43. Saxena, M.P.; Saxena, H. Histopathological changes in lymphoid organs of fish after exposure to water polluted with heavy metals. Int. J. Vet. Med. 2008, 5, 1-3.

44. Ayandiran, T.A.; Fawole, O.O.; Adewoye, S.O.; Ogundiran, M.A. Bioconcentration of metals in the body muscle and gut of Clarias gariepinus exposed to sublethal concentrations of soap and detergent effluent. J. Cell Animal Biol. 2009, 3, 113-118.

45. Gabriel, U.U.; Mark, P.; Orlu, E.E. Toxicity and behavioural changes in Heterobranchus bidorsalis fingerlings treated with a micronutrient. Fertilizer, agrolyser. Res. J. Environ. Earth Sci. 2009, 1, 34-38.

46. Ololade, I.A.; Oginni, O. Toxic stress and haematological effects of nickel on African catfish, Clarias Gariepinus, fingerlings. J. Environ. Chem. Ecotoxicol. 2010, 2, 14-19.

47. Strauss, M. Survival of excreted pathogens in excreta and faecal sludges. IRCWD News 1985, 23, 4-9.

(C) 2011 by the authors; licensee MDPI, Basel, Switzerland. This article is an open access article distributed under the terms and conditions of the Creative Commons Attribution license (http://creativecommons.org/licenses/by/3.0/). 